\title{
The relatioship beetwen levels of altruism, empathy and assertiveness in nursing students
}

\author{
Związek pomiędzy poziomem altruizmu, empatii \\ a asertywnością wśród studentów pielęgniarstwa
}

\author{
Ş. DILEK GÜVEN ${ }^{1}$, AYLA ÜNSAL 2 \\ ${ }^{1}$ Nevşehir Hacı Bektaş Veli University Semrave Vefa Küçük Health School, Nursing \\ Department \\ ${ }^{2}$ Ahi Evran University, School of Health, Nursing Department Kırşehir \\ DOI: http://dx.doi.org/10.21784/lwP.2019.010 \\ ISSN: 2451-1846
}

\begin{abstract}
:
Intoduction. It is obvious that altruism, empathy and assertiveness have a direct relationship with the nursing profession. Moreover, altruism, empathy and assertiveness are the values that have to be fostered in nurses in their development of a professional identity during their education. Professional values and attitudes also promote development of professional characteristics including the definition of humanistic care and professional identity. The purpose of this study is to determine the relationship of altruism with empathy and assertiveness in nursing students.

Aim. The purpose of thisstudy is todetermine the relationship of altruism with empathy and assertiveness in nursing students.

Material and Methods: This is a descriptivestudy.This study was conducted with 659 nursing students in the Nursing Departments of the Health Colleges of two universities in the Central Anatolia Region of Turkey. The data were collected using a Personal Information Questionnaire, the Altruism Scale, Empathic Tendency Scale and Ruthus Assertiveness Inventory. In analyzing
\end{abstract}


the data, percentage distribution, mean standard deviation, correlation analysis, and confidence analysis were used.

Results: The students' mean altruism score was found to be $62.69 \pm 11.35$, their mean empathic tendency score $66.25 \pm 11.05$ and their mean Ruthus Assertiveness Inventory score $7.36 \pm 15.52$. A positive linear and statistically significant correlation was found between the altruism and empathic tendencies of the students who took part in the study $(\mathrm{r}=0.181, \mathrm{p}=0.000)$ and between their altruism and Ruthus Assertiveness Inventory levels $(r=0.186$, $\mathrm{p}=0.000$ ).

Conclusion. As the students' empathic tendencies and assertiveness increase, the level of their altruism also increases.

Keywords: altruism, empathic tendency, assertiveness, nursing students

\section{Streszczenie:}

Wstęp. Oczywistym jest, że altruizm, współczucie i asertywność to pojęcia, które mają bezpośredni związek z zawodem pielęgniarki. Co więcej, altruizm, empatia i asertywność to wartości, które muszą być pielęgnowane przez pielęgniarki w rozwijaniu tożsamości zawodowej podczas ich edukacji. Profesjonalne wartości i postawy promują również rozwój cech zawodowych, w tym definicje opieki i tożsamości zawodowej. Celem tego badania jest określenie związku pomiędzy altruismem, empatią a asertywnością u studentów pielęgniarstwa.

Cel. Celem tego badania jest określenie związku pomiędzy altruizmem, empatią a asertywnością u studentów pielęgniarstwa.

Materiał i metody. Jest to badanie opisowe. Badanie zostało przeprowadzone wśród 659 studentów pielęgniarstwa na wydziałach pielęgniarskich kolegiów zdrowia dwóch uniwersytetów w regionie Centralnej Anatolii w Turcji. Dane zostały zebrane za pomocą kwestionariusza osobowego, skali altruizmu, Empathic Tendency Scale i Ruthus Assertiveness Inventory W analizie danych zastosowano rozkład procentowy, średnie odchylenie standardowe, analizę korelacji i analizę ufności.

Wyniki. Średni wynik oceny altruizmu studentów wynosił $62,69 \pm 11,35$,ich średnia skłonność do empatii/ średnia cena postawy empatycznej wynosi $66,25 \pm 11,05$, a ich średnia ocena Ruthus Aseriveness Inventory 7,36 \pm 
15,52. Stwierdzono dodatnią liniową i statystycznie istotną korelację między altruizmem a postawami empatycznymi/skłonnością do empatii studentów , którzy wzięli udział $\mathrm{w}$ badaniu $(\mathrm{r}=0,181, \mathrm{p}=0,000)$ oraz między ich altruizmem a poziomem Assertiveness Inventory Ruthus $(\mathrm{r}=0,186, \mathrm{p}=$ $0,000)$.

Wnioski. Wraz ze wzrostem skłonności do empatii studentów i ich asertywności wzrasta również poziom ich altruizmu.

Słowa kluczowe: altruizm, tendencja empatyczna, asertywność, studenci pielęgniarstwa

\section{Introduction}

Altruism is defined as attention and care without any expectation other than the belief in helping and benefiting others or protecting them from harm [1]. The objective of the professionals whose fundamental values include altruism is to serve and help humans and to contribute to social development [2]. Nursing has been described throughout the history as one of the helping/altruist professions. It has been stated that altruism is at the foundation of nursing and people with a high level of altruism choose the profession of nursing because they wish to help people with a deep affection $[2,3]$.

Despite some views defending that psychomotor skills lie at the root of nursing care, sources state that nursing care practices cannot be explained either mechanically or depending on the skills of the practitioner; the power behind these skills relate only to the creativity, sensitivity and communication competency of nurses. For this reason, besides improving their psychomotor skills, nurses are expected to be at a desired level in creativity, interpersonal sensitivity, empathy and communication skills [3].

The process is called empathy when someone puts himself in the place of the person he faces, looks at the events from their point 
of view, understands and feels that person's emotions and thoughts correctly and conveys this to them. Empathic tendency is the potential of an individual to show empathy. Empathic tendency is reported to be the ability to understand the feelings of the client and being affected by their emotional experiences and the willingness to help [4]. Looking at them from this perspective, empathic tendencies produce positive impact on altruistic behavior and empathic tendency is used as a criterion in defining altruistic behavior [5]. Empathic capacity and tendency are reported to lead to altruistic behaviors to relieve the troubles of others [6,7]. People who have empathic tendencies help a person they perceive to be in need at a higher rate [8].

When an individual claims his personality, dignity and rights, expresses his views, feelings and thoughts honestly and directly, respecting the beliefs and needs of others as much as he respects his own beliefs and needs without being passive but without being aggressive either, this is called assertiveness [9]. The fact that nursing profession is totally people oriented, coordinated and actual, it follows that nurses have to be assertive [10]. Khalil has stated that people cannot help others because they are not assertive [11]. This implies that altruist behaviors can be seen more commonly in assertive people. Ismenand Yildizhave demonstrated in their study with teachers that assertive people are more altruistic compared to meek people [12]. Rushton, Fulker, Neale, NiasandEysenck[13]have found a positive correlation between assertiveness and altruism.

It is obvious that altruism, empathy and assertiveness have a direct relationship with the nursing profession. Moreover, altruism, empathy and assertiveness are the values that have to be fostered in nurses in their development of a professional identity during their education. Professional values and attitudes also promote development of professional characteristics including the definition of humanistic care and professional identity [14,15]. Altruism, empathy and assertiveness are necessary values for professional nursing practices. In this context, we believe that the results to be obtained from 
examination of these values will provide guidelines for the training and practices towards assimilating these values and useful information for developing more effective strategies. For this reason, we aimed at determining the relationship of altruism level in nursing students with their empathy and assertiveness in the present study.

The purpose of this study is to determine the relationship of altruism with empathy and assertiveness in nursing students.

The study sought answers to the following questions:

- What are the altruism levels, empathic tendency levels and boldness levels of nursing students?

- Is there a relationship between the altruism, empathic tendency and boldness levels of nursing students?

\section{Material and Methods}

\section{Design and Sample}

The population of this descriptive study consisted of 1050 nursing students in the Nursing Departments of the Health Colleges of two universities in the Central Anatolia Region of Turkey. No sampling was attempted and the study was completed with 659 students due to absences and unwillingness to participate. The study data were collected from April to May 2015. The study data were collected using a Personal Information Questionnaire, the Altruism Scale, Empathic Tendency Scale and Ruthus Assertiveness Inventory. The questionnaire and scales were distributed by the investigators to the students in their classrooms and were collected after they were completed. Permissions were obtained before starting the study from the institutions where the study was conducted and from the students. 


\section{Instruments}

Personal Information Questionnaire: The questionnaire consisted of 5questionsto determine the students' ages, genders, marital statuses, grades and satisfaction with their choice of profession.

Altruism Scale (AS):This was developed by London and Bower [16] and was tested for validity and reliability in Turkish by Akbaba[17]. The scale has 20 items. It is a likert-type scale where 1 stands for the lowest and 5 the highest. The points marked are summed to obtain the total score, the highest obtainable being 100 and the lowest 20. Higher scores indicate higher levels of altruism and lower scores lower levels of altruism. The scale's Cronbach Alpha value is 0.85 . The scale's Cronbach Alpha value was calculated to be 0.81 in our study.

Empathic Tendency Scale (ETS):ETS was developed by Dokmen[18] tomeasure the empathizing potential of individuals in daily life. It is a likert-type scale consisting of 20 questions, each of which is scored from 1 to 5 . The minimum score obtainable from the scale is 20 and the maximum is 100 . A high score indicates a high empathic tendency and a low one a low empathic tendency. The scale's Cronbach Alpha value is 0.88 . The scale's Cronbach Alpha value was calculated to be 0.81 in our study.

Rathus Assertiveness Inventory (RAI):It was developed by Spencer Rathus to measure assertiveness in interpersonal relationships and was tested for validity and reliability in Turkish by Voltan[19]. RAI consists of 30 items containing positive and negative statements. The assertiveness score is obtained by adding the numeric values of the positive statements and the numeric values of the negative statements separately. The responses to the positive statements $(3,6,7,8,10,18$, $20,21,22,25,27,28$ and $29-13$ items) are "very much like me" (+3 points), "rather like me" (+2 points), "somewhat like me" (+1 point), "somewhat unlike me" (-1 point), "rather unlike me" (-2 
points), "very unlike me" (-3 points) and the responses to negative statements $(1,2,4,5,9,11,12,13,15,16,17,19,23,24,26$ and $30-$ 17 items) are "very much like me" (-3 points), "rather like me" (-2 points), "somewhat like me" (-1 point), "somewhat unlike me" $(+1$ point), "rather unlike me" (+2 points), "very unlike me" (+3 points). The total score obtainable ranges between -90 and +90 . In scoring RAI, a score between -90.00 and +10.00 is assessed in the category of being meek/passive, a score between +11.00 and +70.00 as being assertive and a score between +71.00 and +90.00 as being aggressive. The scale's Cronbach Alpha value is 0.70. The scale's Cronbach Alpha value was calculated to be 0.60 in our study.

\section{Data Analysis}

The data were analyzed electronically in the study. Percentage distribution, mean standard deviation, correlation analysis and confidence analysis were used in the statistical analyses. A value of $p<0.05$ was accepted as significant in the statistical tests.

\section{Results}

From the students taking part in the study, $72.9 \%$ were female, $1.5 \%$ married, $36.4 \%$ were in their first year, $30.8 \%$ in their second year, $20.0 \%$ in their third year, and $12.7 \%$ in their fourth year. Their ages ranged between 17 and 35, with a mean age of 20.56 \pm 1.90 . $53.7 \%$ of the students were graduates of ordinary high school and $88.5 \%$ of them had nuclear type families. The mothers of $62.4 \%$ of the students and the fathers of $47.2 \%$ of them were graduates of primary school; the mothers of $84.5 \%$ and the fathers of $28.5 \%$ were unemployed. $27.2 \%$ of the students had one sibling, $61.3 \%$ had $1-10$ close friends, and $68.4 \%$ described him/herself as being a conformist/cheerful person. $50.8 \%$ of the students stated that they were pleased to have chosen the nursing profession. 
Table 1. Students' mean scores of altruism, empathic tendency and RAI (n=659)

\begin{tabular}{|l|l|l|l|l|}
\hline Variables & $\mathbf{X} \pm$ SD & Min & Max & $\begin{array}{l}\text { Score } \\
\text { Interval }\end{array}$ \\
\hline Altruism & $62.69 \pm 11.35$ & 20 & 92 & $20-100$ \\
\hline $\begin{array}{l}\text { Empathic } \\
\text { tendency }\end{array}$ & $66.25 \pm 11.05$ & 27 & 93 & $20-100$ \\
\hline RAI & $7.36 \pm 15.52$ & -33 & 72 & $-90-+90$ \\
\hline
\end{tabular}

Source: own research results

The students' mean altruism score turned out to be $62.69 \pm 11.35$, mean empathic tendency score $66.25 \pm 11.05$ and mean RAI score $7.36 \pm 15.52$ (Table 1 ).

Table 2. Correlation between the students' altruism and their empathic tendency and RAI levels $(n=659)$.

\begin{tabular}{|l|l|l|l|}
\hline & \multicolumn{3}{|l|}{ Altruism } \\
\hline & $\mathbf{n}$ & $\mathbf{r}$ & $\mathbf{p}$ \\
\hline $\begin{array}{l}\text { Empathic } \\
\text { tendency }\end{array}$ & 659 & 0.165 & 0.000 \\
\hline RAI & 659 & 0.183 & 0.000 \\
\hline
\end{tabular}

Source: own research results

We found a positive, linear and statistically significant correlation between the participating students' altruism and empathic tendencies $(r=0.181, p=0.000)$ and their altruism and RAI levels $(r=0.186, p=0.000)$ (Table 2). 
Table 3. Comparison of certaincharacteristics of thestudentswiththemeanscores of Altruism, EmpathicTendencyand RAE( $(n=659)$.

\begin{tabular}{|c|c|c|c|}
\hline Variables & $\begin{array}{l}\text { Altruism range } \\
\text { of points } \\
(20-100) \\
X \pm S D\end{array}$ & $\begin{array}{l}\text { EmpathicTenden } \\
\text { cy range of } \\
\text { points } \\
(20-100) \\
X \pm S D\end{array}$ & $\begin{array}{l}\text { RAE range } \\
\text { of points } \\
(-90-+90) \\
\text { X } \pm \text { SD }\end{array}$ \\
\hline \multicolumn{4}{|l|}{ Age Group } \\
\hline Under 20 & $66.22 \pm 10.79$ & $62.69 \pm 11.69$ & $9.36 \pm 15.84$ \\
\hline $21-25$ & $66.12 \pm 11.34$ & $62.30 \pm 10.88$ & $6.04 \pm 14.85$ \\
\hline $26-29$ & $67.00 \pm 12.81$ & $71.25 \pm 8.68$ & $5.12 \pm 20.15$ \\
\hline $30-35$ & $76.75 \pm 6.23$ & $73.00 \pm 4.08$ & $15.75 \pm 7.63$ \\
\hline Test** & $\mathrm{X}^{2}=4.627 \mathrm{p}=0.201$ & $\begin{array}{l}X^{2}=9.168 \\
p=0.027\end{array}$ & $\begin{array}{l}X^{2}=13.699 \\
p=0.003\end{array}$ \\
\hline \multicolumn{4}{|l|}{ Gender } \\
\hline Women & $65.86 \pm 10.91$ & $62.38 \pm 11.72$ & $8.08 \pm 15.48$ \\
\hline Men & $67.46 \pm 11.38$ & $63.68 \pm 10.06$ & $7.06 \pm 15.71$ \\
\hline Test* & $\mathrm{Z}=-1.525 \mathrm{p}=0.303$ & $\mathrm{Z}=-1.030 \mathrm{p}=0.127$ & $\begin{array}{l}Z=-0.619 \\
p=0.536\end{array}$ \\
\hline \multicolumn{4}{|l|}{ Class of study } \\
\hline 1. & $66.45 \pm 10.61$ & $62.94 \pm 11.57$ & $\begin{array}{l}10.56 \pm 16.9 \\
0\end{array}$ \\
\hline 2. & $65.81 \pm 11.66$ & $63.46 \pm 10.74$ & $7.78 \pm 15.16$ \\
\hline 3. & $66.42 \pm 12.00$ & $61.00 \pm 11.95$ & $2.69 \pm 11.93$ \\
\hline 4. & $66.46 \pm 9.00$ & $62.79 \pm 11.11$ & $9.23 \pm 15.46$ \\
\hline Test ${ }^{* *}$ & $\mathrm{X}^{2}=0.085 \mathrm{p}=0.994$ & $\mathrm{X}^{2}=2.969 \mathrm{p}=0.396$ & $\begin{array}{l}X^{2}=25.052 \\
p=0.000\end{array}$ \\
\hline \multicolumn{4}{|l|}{ Family type } \\
\hline Nuclearfamily & $66.08 \pm 11.14$ & $62.75 \pm 11.47$ & $8.16 \pm 15.50$ \\
\hline Broadfamily & $68.81 \pm 9.95$ & $62.37 \pm 10.62$ & $6.43 \pm 14.53$ \\
\hline Brokenfamily & $59.40 \pm 8.63$ & $61.40 \pm 9.94$ & $6.60 \pm 23.41$ \\
\hline
\end{tabular}




\begin{tabular}{|l|l|l|l|}
\hline Test $^{* *}$ & $\begin{array}{l}\mathbf{X}^{2}=\mathbf{8 . 3 7 4} \\
\mathbf{p}=\mathbf{0 . 0 1 5}\end{array}$ & $\mathrm{X}^{2}=0.284 \mathrm{p}=0.868$ & $\begin{array}{l}\mathrm{X}^{2}=1.845 \\
\mathrm{p}=0.397\end{array}$ \\
\hline \multicolumn{3}{|l|}{} \\
\hline $\begin{array}{l}\text { Described themselves } \\
\text { and joyful }\end{array}$ & $67.21 \pm 10.99$ & $62.99 \pm 11.45$ & $\begin{array}{l}10.13 \pm 15.6 \\
2\end{array}$ \\
\hline $\begin{array}{l}\text { Nervous- } \\
\text { stressed }\end{array}$ & $63.47 \pm 12.25$ & $61.52 \pm 10.96$ & $5.82 \pm 15.20$ \\
\hline $\begin{array}{l}\text { Hesitant- } \\
\text { fragile }\end{array}$ & $64.90 \pm 9.21$ & $62.62 \pm 11.35$ & $0.47 \pm 12.66$ \\
\hline $\begin{array}{l}\text { Test } \\
\text { ** }\end{array}$ & $\begin{array}{l}\mathbf{X}^{2}=\mathbf{1 1 . 5 9 7} \\
\mathbf{p}=\mathbf{0 . 0 0 3}\end{array}$ & $\mathrm{X}^{2}=2.232 \mathrm{p}=0.328$ & $\begin{array}{l}\mathbf{X}^{2}=\mathbf{3 8 . 6 1 0} \\
\mathbf{p}=\mathbf{0 . 0 0 0}\end{array}$ \\
\hline Pleased with their profession & \multicolumn{2}{|l}{} \\
\hline Not pleased & $61.78 \pm 14.28$ & $60.36 \pm 12.08$ & $7.21 \pm 18.20$ \\
\hline $\begin{array}{l}\text { Middlingpleas } \\
\text { ed }\end{array}$ & $64.70 \pm 10.80$ & $60.31 \pm 10.55$ & $6.76 \pm 15.03$ \\
\hline Pleased & $68.15 \pm 10.35$ & $64.99 \pm 11.45$ & $9.06 \pm 15.50$ \\
\hline Test & $\begin{array}{l}\mathbf{X}^{2}=\mathbf{1 8 . 8 2 8}=\mathbf{0 . 0} \\
\mathbf{0 0}\end{array}$ & $\begin{array}{l}\mathbf{X}^{2}=\mathbf{3 0 . 3 9 8 p}=\mathbf{0 . 0} \\
\mathbf{0 0}\end{array}$ & $\begin{array}{l}\mathbf{X}^{2}=\mathbf{7 . 2 7 6} \\
\mathbf{p}=\mathbf{0 . 0 2 6}\end{array}$ \\
\hline
\end{tabular}

*Mann Whitney U test

*Kruskal Wallis test

Source: own research results

A review of the mean overall Altruism Scale scores of the students (Table 3) showed that the students who lived in a broad family, described themselves as well-adjusted / joyful and were pleased with their profession had higher mean overall altruism scores; age, gender and the class in which they studied did not affect the mean overall scores $(p<0.05)$. The mean emphatic tendency scores were higher in students aged between 30 and 35 and who were pleased with their profession; there were no statistically significant changes between the mean scores with respect to gender, the class in which they studied, self-description, and family type $(p<0.05)$. The mean RAE scores were 
higher in the students who were aged between 30 and 35, who studied in the first class, who described themselves as well-adjusted / joyful and who were pleased with their profession; there was no significant difference in the mean scores with respect to gender and family type $(p<0.05)$.

\section{Disscusion}

Altruist behavior is quite valuable in the profession groups that provide healthcare services because altruist people act for the benefits of others rather than for their own interests [20]. Altruism is one of the professional values that form the basis of nursing practices and nursing has been defined as one of the most helpful/altruist occupations throughout its history [21,3,8]. Pehlivan and Lafçı [22] found in their study that the mean altruism score of nursing students was $66.28 \pm 10.29$, indicating that they were altruist above the moderate level; Avcı, AydınandÖzbaşaran [23] found in their study that the mean altruism score of nursing students was 70.16 \pm 9.94 , indicating that they were altruist above the moderate level; and Arpacı and Özmen[24] found in their study that the overall mean altruism score of nursing students was $72.85 \pm 8.18$, again indicating that they were altruist above the moderate level [22]. As a result of our study, we also found that theoverall mean altruism score of nursing students was $62.69 \pm 11.35$, showing that the students were altruist above the moderate level(Table 1). Based on this result of our study, which is similar to those of other studies, we can say that nursing students have the merit of altruism as one of the professional values of nursing, and having this merit, they will wish to help people with a deep affection.

The ability to empathize is significant in establishing sound interpersonal communication. Healthy communication enables understanding and being understood. For this reason, nurses should 
have the skills to empathize their patients to be able to understand them. When nurses fail to empathize effectively, it will be impossible for them to understand the feelings and thoughts of their patients. Empathy and communication skills are important to achieve a good quality nursing care [25].

Avcl, Aydın andÖzbaşaran[23] reported in their study that the mean empathic tendency score of nursing students was $67.66 \pm 6.20$. In their study to determine the effect of education on empathic tendency, Karaca, Açıkgöz and Akkuş [26]found that the pre-education mean empathic tendency score of nursing students was $163.6 \pm 29.03$. The mean empathic tendency score of nursing students turned out to be X: 69.55 in the study of Tutuk, Al and Doğan[27] and 69.94 \pm 8.44 in the study of Arpacı and Özmen [24]. As in other studies made in Turkey, our study also showed that the empathic tendency of nursing students was at a moderate level $(66.25 \pm 11.05)$ (Table 1). These results suggest that the necessary changes should be made and implemented in the nursing education programs to improve the empathic tendencies of nursing students beyond the moderate level they had during their education. People with higher empathic tendencies demonstrate more helping behavior [25]. It has been reported that nurses with a higher tendency to empathize have a better chance of identifying patient problems and helping them more effectively than those with a lower empathic tendency [28]. Arpacı and Özmen [24] have found in their study a positive but weak correlation between altruism and empathic tendency among nursing students. Mehrabian and Epstein [29] have found a positive correlation between helpfulness and empathic behavior. In their study investigating the relationship between empathy and altruism in nursing students, Avcl, Aydın andÖzbaşaran[23] have found a positive and statistically significant correlation between the empathic tendencies and altruism levels of students. We also found in our study a positive and statistically significant correlation between altruism and empathic tendency (Table 2). This result means that as the empathic tendencies of nursing 
students increase, their altruism levels also increase. In the light of this result of our study, we think that providing nurses with education to develop their altruism and empathic tendency during their nursing education will contribute to the improvement of the relationship between altruism and empathy.

In order for health professionals to be able to provide quality healthcare services and be satisfied with the services they provide, they need to be bold type of persons [30]. We found in our study that the nursing students were timid/passive as evidenced by their mean RAE score (Table 2). Contrary to our study result, other studies made in Turkey have shown that nursing students are bold [30,31,32,33]. This result of our study suggests that the educational activities to improve the level of boldness of the nursing students in the schools where our study was carried out should be reviewed and improved We also found in our study a statistically significant correlation in the positive direction between the altruism and RAE levels of the nursing students (Table 2). This result means that as the level of boldness increases in nursing students, the level of their altruism also increases. It also shows that increasing the boldness of nursing students during their education will lead to an increase in the level of their altruism.

It has been reported that tendency for altruism lies in the foundation of nursing practices and persons with a high tendency for altruism choose the nursing profession because they wish to help people with a deep affection [34]. The study results also showed that students who were pleased with their profession had higher mean altruism scale scores than those who were not pleased with their profession (Table 3). This result is important in determining the magnitude of the helping care that should be given by nurses to healthy and ill individuals/families, and the society so that they can provide more comprehensive and qualified care today and in the future.

Altruistic behavior is reported to take place as a result of learning and to improve in a supportive and coherent family 
environment that will serve as a positive model [23]. The present study results showed that students living in broad family environment had higher mean altruism scores than those living in nuclear or broken families (Table 3). This result suggests that students with broken families had also less responsibility towards their family in the past compared to students with broad families and shows that a positive family model has an impact on altruism.

It has been reported in the literature that altruistic behavior makes a person happy and it is a type of behavior that suits the sense of duty [34]. The results of the present study also suggest that altruistic behavior increases happiness and makes one feel pleased as the students who described themselves as well-adjusted and joyful had higher scores of altruism (Table 3).

Empathy is known to lead to altruistic behaviors to relieve others' troubles and it forms the basis for altruistic behavior [23]. The results of the present study showed that the mean emphatic tendency scores of the students were higher between ages 30 and 35 (Table 3). Nazik and Aslan[35] have found in their study with nursing students that the empathic skills improve with advancing age. Increased tendency for empathy with advancing age shows that individual age is effective on the tendency for empathy.

The study results showed that the mean Emphatic tendency scores were higher in students who were pleased with their profession (Table 3). It was also found in the study of Arpacı and Özmen [24] that those who were pleased with studying in the nursing department had higher empathic tendency scores. These results are important in that they show, as in the literature, that persons who are pleased with their profession and have high Empathic tendencies will be more inclined to help the person they think is in need [23].

The finding in the study results that the students who were aged between 30 and 35, who described themselves as well-adjusted / joyful and who were pleased with their profession had higher mean RAE scores (Table 3) is important not only in the sense of educating 
today's students as future nurses who are more extroverted, are able to establish healthy relationships, and have high levels of selfacceptance, self-confidence and self-respect, but also in the sense of personal fulfillment and professional satisfaction[25]. Their level of extroversion will also be influenced by their education life, adaptation to the university life, advancing age, increasing clinical skills, adaptation to hospital setting, learning and implementing the techniques for communication and coping with stress [32].

Looking at the mean RAE scores of the students with respect to their grades, we see that the students studying in the $1^{\text {st }}$ class had higher mean scores than those studying in other classes (Table 3). Similar to our study results, some studies have also reported that nursing education as a pressuring and stressful experience affects the level of boldness in the students negatively with boldness scores dropping with advancing grades [32]. According to Begley and Glacken [36], pressure is felt by nurses in both their classes and clinics starting from their early years of education. Similar to our results, this situation is important as it may prevent care to be practiced at the desired level by affecting the quality of the services provided by nurses.

In conclusion, there was a statistically significant correlation in the positive direction between the altruism and empathic tendencies of the students and between their altruism and RAE levels. This follows that as the empathic tendencies and boldness levels of students increase, their altruism also improves.

\section{Conclusions}

We found in our study that as students' empathic tendencies and assertiveness levels increased, their altruism levels also went up. 


\section{Recommendations}

The results of our study shows that in nursing education empathic tendency and assertiveness should be improved in students so that their professional altruistic values are also improved and there is a need to carry out the activities required to achieve this in nursing education.

\section{Limitations}

The present study covered the students of Nursing Department of the Health Collages of only two universities in the Central Anatolia Region of Turkey; therefore, the results obtained from the study cannot be generalized to all nursing students.

\section{Bibliography/Bibliografia:}

1.Ersanlı K., Çabuker N.D. Psychometric properties of the altruism scale. Electronic Journal of Social Silences 2015; 14(52), 43-53. http://dx.doi.org/10.17755/esosder.70589

2.Öz F. Altitude in nursing (helping). Journal of Cumhuriyet University School of Nursing 1998; 2(1):53- 58.

3.Gormle K.J. Altruism: a framework for caringand providing care. International Journal of NursingStudies 1996; 33(6), 581-588. https://doi.org/10.1016/S0020-7489(96)00013-2

4.Dökmen Ü. Communication Conflicts and Empathy (İletişim Çatışmaları ve Empati) 2005; 5nd ed. İstanbul, Sistem Yayıncllık. 
5.Eisenberg N., Fabes R.A., Spinrad T.L. Prosocialdevelopment, Damon W, Lerner RM (eds): Handbook of Child Psychology. 2006; John Wiley\&Sons, Newyork, pp. 646-719.

6.Batso C.D. Altruismandprosocialbehavior, Weiner IB (ed): Handbook of SocialPsychology 2003; John Wiley\&Sons, Inc., Newyork, pp. 463-485.

7.Eisenberg N. Distinctions among various modes of empathy-related reactions: A matter of importance in humans. Behavioraland Brain Sciences 2002; 25(1), 33-34. https://doi.org/10.1017/S0140525X02350015

8.McCamant K.L. Humanistic nursing, interpersonal relations theory, and the empathy-altruism hypothesis. Nursing Science Quarterly 2006; 19(4), 334338.

9.Özcan A. Hemşire-Hasta İlişsisi ve İletişim. 2nd ed. 2006; Ankara, Simtel Ofset.

10.Batmaz M., Buzlu S., Kutlu Y., Pektekin C.. Investigation of the assertiveness leveland self-esteem of the senior students of Istanbul University Health Services Vocational School Nursing Program. Nursing Bulletin 1999; 11(43-44), 173-183.

11.Khalil E.L. What is altruism? Journal of Economic Psychology 2004; 25(1), 97-123. https://doi.org/10.1016/S0167-4870(03)00075-8

12.Ismen A.E., Yildiz S.A.The relationship between altruism, assertiveness and attitudes toward steaching profession. Educational Administration: Theory and Practice 2005; 42, 151-166.

13.Rushton J.P., Fulker D.W., Neale M.C., Nias D.K., Eysenck, H.J. Altruism and aggression: The heritability of individual differences. Journal of Personality

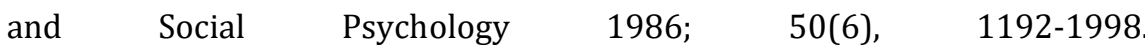
http://dx.doi.org/10.1037/0022-3514.50.6.1192

14.Hoyuelos S.B., Fraile C.L., Weis D., Urien E.D.L., Elsden C.A., Schank, M.J. Nursing profession a values: validation of a scale in a Spanishcontext. Nurse 
Education Today 2010; 30(2), 107-112.

https://doi.org/10.1016/j.nedt.2009.05.010

15.Bang K. S., Kang J. H., Jun M. H., Kim H. S., Son H. M., Yu S. J., Known M.K., Kim J.S. Professional values in Korean undergraduate nursing students. Nurse EducationToday 2011; 31(1), 72-75.

https://doi.org/10.1016/j.nedt.2010.03.019

16.London P., Bower R.K. Altruism, extraversion, andmentalillness. The $\begin{array}{lllll}\text { Journal of } & \text { social psychology } 1968 \text { 76(1), } & \text { 19-30. }\end{array}$ http://dx.doi.org/10.1080/00224545.1968.9919819

17.Akbaba S.: Validity and reliability study of adaptation of the scale of Turkishness to Turkish. Erzincan University Journal of Education Faculty 2001; 3(2), 85-95.

18.Dökmen Ü.: Measuring empathy based on a model and improving it by psychodrama. Ankara University Journal of Faculty of Educatıonal Sciences 1998; 21(1-2), 155-190.

19.Voltan N. RathusAssertiveness Inventory validity and reliability study. Journal of TurkishPsychology 1980; 10, 23-25.

20.Kılınç E., Kılıç M., İpekçi N. Sağlık Hizmetleri Meslek Yüksek Okulu Öğrencilerinin Benlik Saygısı, Atılganlık ve Özgecilik Düzeyler ile Aralarındaki İlişkinin İncelenmesi. Karadeniz Sosyal Bilimler Dergisi 2016; 8(15); 379-398.

21.Rognstad M.K., Nortvedt P., Aasland O. Helping motives in late modern society: values and attitudes among nursing students. Nursing Ethics 2004; 11(3), 227-239.

22.Pehlivan S., Lafçı D. Altruism levels of nursing students, Gaziantep Medical Journal 2014; 20(1), 29-34.

23.Avcı D., Aydın D., Özbaşaran F. The relation of empathy-altruism and the investigation of altruistic behaviour with regard to some variables of nursing 
students. Balıkesir Healthand Sciences Journal 2013; (2), 108-113. https:// doi.org/10.5505/bsbd.2013.04706

24.Arpacı P., Özmen D.: Levels of nursing students and the relationship between altruism and empathic tendencies. Journal of Nursing Education and Research 2014; 11(3), 51-57.

25.Cen H.T., Yilmaz F.T., Unuvar O.P., Demirkaya F.: Emphatic skill levels of primary health care workers. Journal of Psychiatric Nursing 2012; 3(1), 613. http://dx.doi.org/10.5505/phd.2012.09797

26.Karaca A., Açıkgöz F., Akkuş D.: Can empathy with empathic skill and empathic tendency be developed? A health care college example. Acıbadem University Journal of Health Sciences 2013; 4(3), 118- 122.

27.Tutuk A., Al D., Doğan S. Determining communication skills and emphatic levels of nursing students. Journal of Cumhuriyet University School of Nursing 2002; 6(2), 36-41.

28.0̈z F. Altitude in nursing (helping). Journal of Cumhuriyet University School of Nursing 1998; 2(1):53- 58.

29.Mehrabian A., Epstein, N.A. Measure of emotional empathy. 1972; http://onlinelibrary.wiley.com/doi/10.1111/j.1467-

6494.1972.tb00078.x/abstract

30.Adana F., Aktaş B., Erdağı S., Eliş S., Alkan H., Uluman Ö. Determining Assertiveness Level of Student Health Officering and Nursing. Journal of Anatolia Nursing and Health Sciences 2009; 12(2), 51-56.

31.Illhan N., Sukut Ö., Akhan L.U., Batmaz M. The effect of nurse education on the self-esteemand assertiveness of nursing students: A four-year longitudinal study. Nurse Education Today 2016; 39, 72-78. https://doi.org/10.1016/j.nedt.2015.12.026 
32.Dinçer F., Öztunç G. Self-esteemand assertiveness levels of nursing and midwifery students. Hacettepe University Faculty of Health Sciences Nursing Journal 2009; 16(2), 22-33.

33.Kahriman İ. Examination of the self-esteemand assertiveness of the students at the School of Health at Karadeniz Technical University in terms of some. Journal of Cumhuriyet University School of Nursing 2005; 9(1), 2432.

34.Banbal G. Altruism levels of nursing students. Istanbul University: Institute of Health Sciences, M.Sc. Thesis. İstanbul: 2010.

35.Nazik E., Arslan S.: Investigation of the relationship between empathy skills and self compassion of nursery students. Journal of Anatolia Nursing and Health Sciences 2011; 14(4),69-75.

36.Begley C.M., Glacken M. Irish nursing students' changing levels of assertiveness during their pre-registration programme. Nurse Education Today 2004; 24(7), 501-510. doi.org/10.1016/j.nedt.2004.06.002

Received: 12.05.2019r.

Accepted: 09.06.2019r. 